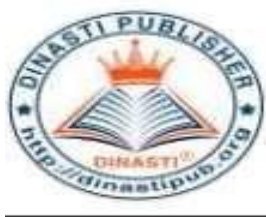

\title{
THE EFFECT OF DISCIPLINE AND TRAINING ON JOB MOTIVATION AND IMPLICATION ON EMPLOYEE PERFORMANCE (STUDY CASE AT PT. VANIA INTERIOR FURNISHING)
}

\section{Santika Maruhun ${ }^{1)}$ Chaerudin $^{2)}$}

${ }^{1,2)}$ School of Business, Master of Management, Universitas Mercu Buana, Jakarta, Indonesia

\begin{tabular}{|c|c|}
\hline $\begin{array}{l}\text { ARTICLE INFORMATION } \\
\text { Received: 24 December } 2019 \\
\text { Revised: } 30 \text { December } 2019 \\
\text { Issued: } 1 \text { January } 2020 \\
\text { Corresponding author: } \\
\text { Santika Maruhun }\end{array}$ & $\begin{array}{l}\text { Abstract: This research was conducted aiming to reveal how } \\
\text { much the impact of Discipline, Training on Job Motivation and } \\
\text { Implication of Employee Performance on employees working at } \\
\text { PT Vania Interior Furnishing, using the PLS (Partial Least } \\
\text { Square) method and structural equation analysis (SEM) based } \\
\text { variants which can simultaneously conduct measurement model } \\
\text { testing along with structural model testing. The results showed } \\
\text { that: (1) There was a positive and significant influence on } \\
\text { Discipline attitude towards Employee Performance at PT. Vania } \\
\text { Interior Furnishing. (2) There is a positive and significant } \\
\text { influence of Discipline on Employee Job motivationatPT. Vania } \\
\text { Interior Furnishing. (3) There is a positive and significant } \\
\text { influence of Job motivation on employee performance at PT. } \\
\text { Vania Interior Furnishing. (4) There is a positive and significant } \\
\text { effect of training on EmployeePerformanceatPT. Vania Interior } \\
\text { Furnishing. (5) There is a positive and significant effect of } \\
\text { training on employee Job motivation at PT. Vania Interior } \\
\text { Furnishing. (6) There is a positive and significant influence of } \\
\text { Job motivation which mediates the effect of Discipline on } \\
\text { Employee Performance at PT. Vania Interior Furnishing. (7) } \\
\text { There is a positive and significant influence of Job motivation } \\
\text { which mediates the effect of work training on employee } \\
\text { performance at PT. Vania Interior Furnishing. } \\
\text { Keywords: Job motivation, Employee performance, Discipline, } \\
\text { Training }\end{array}$ \\
\hline
\end{tabular}

\section{INTRODUCTION}

The emergence of the ongoing era of globalization is marked by the occurrence of many rapid changes in various sectors of human life, where the phenomenon is not spared from changes in overall economic conditions. As a result, many organizations are faced with conditions that are completely uncertain, increasingly competitive levels of competition, and various other conditions that can not be negotiable, so that economic agent can not avoid these changes. 
There are several variables that affect employee performance, one of which is the level of discipline. Discipline itself is one of the most important functions of human resource management and is the key to achieving goals. Without good discipline, economic agent will find it difficult to achieve maximum goals.

Other variables that are sufficient to influence employee performance are training, training is very important, because to achieve the desired competencies one of them is through training because employee competency levels and abilities are different and it must be honed properly.

After the results of a survey of employees at PT Vania Interior Furnishing regarding the problems experienced while working. The results of employee responses regarding issues of job satisfaction, compensation and transformational leadership show good responses. However, the motivational response and training provided is not yet optimal. Employees with high Job motivation will try to show their achievements to be better and have the desire to affiliate with others to achieve a higher career. For this reason, the researcher decides to divide the research variables into Ind ependent and Dependent variables, where employee performance is used as the dependent variable, while the independent variables used consist of Job motivation, discipline style, and training where the three independent variables will be further investigated.

\section{LITERATURE REVIEW}

\section{Employee performance}

Priansa (2014: 269) states that performance in English is called job performance, actual performance, or level of performance. Is the level of success of employees in completing their work. High performance is a practice of the level of employee involvement, capacity building and motivation (Armstrong, 2014: 58). In fulfilling high performance, there are several component that must be considered, among others: Through these two definitions, it can be concluded that performance appraisal is a process of performance evaluation carried out by an organization on its employee. Performance appraisal is done so that the organization and employees assessed can know the performance standards they have

\section{Discipline}

Work discipline is one thing that is very important and is applied in an organization in the company. part of the system of work is based on the level of discipline of a worker in carrying out his work. A worker who works well with discipline certainly makes it easy for a company to achieve its goals. according to Hasibuan (2013) discipline means that employees always come and go home on time, do all their work well, and comply with all company regulations and applicable social norms. Singodimedjo (in Sutrisno 2013) states that discipline is an attitude of willingness and willingness to obey and obey the norms of regulations that apply around it. From the understanding of discipline according to the expert, it can be concluded that discipline in an organization is really needed to smooth out all the existing affairs. For example, an errand boy in an office who is late in coming, as a result the workspace in the office are all locked up, so that the office's activities become disrupted, because there are no employees who can carry out their activities, thus disrupting the operations process that day 


\section{Job Motivation}

Sunyoto Danang (2012: 191) defines motivation as a stimulant of one's willingness to work, each motive has a specific goal to be achieved. Whereas Asa'ad in Pasolog, Harbani (2010: 140), motivation is something that creates enthusiasm or work motivation. Mangkunegara (2016: 95) revealed that motives are an impulse of needs in employees that need to be met so that employees can adjust to their environment, while motivation is a condition that moves employees to be able to achieve the goals of their motives. Hasibuan (2014: 222) states that motivation is the provision of movement that creates the excitement of someone's work so that they will cooperate, work effectively and be integrated with all their efforts to achieve satisfaction.

\section{Training}

According to Dessler (2013), training is the process of teaching new employees or those currently working on the basic skills they need to do their jobs.

According to Dessler (2011), Training is a planned effort made by a company to facilitate competency learning related to employee work. These competencies include knowled ge, skills or behaviors that are extremely important for the successful implementation of work. For most organizations, efforts to develop and train human resources (HR) are part of investment because without trained and knowledgeable human resources it will be difficult to realize the organization's vision, mission and goals, especially in the current era of global competition. As a determinant of competitive advantage in an organization, HR has a number of potential advantages derived from physical (energy, physical health and physical readiness) and psychology (thoughts, attitudes, behavior, motivation, creativity and innovation).

\section{A Conceptual Model}

Based on theory and concepts, then the conceptual framework is described as follows

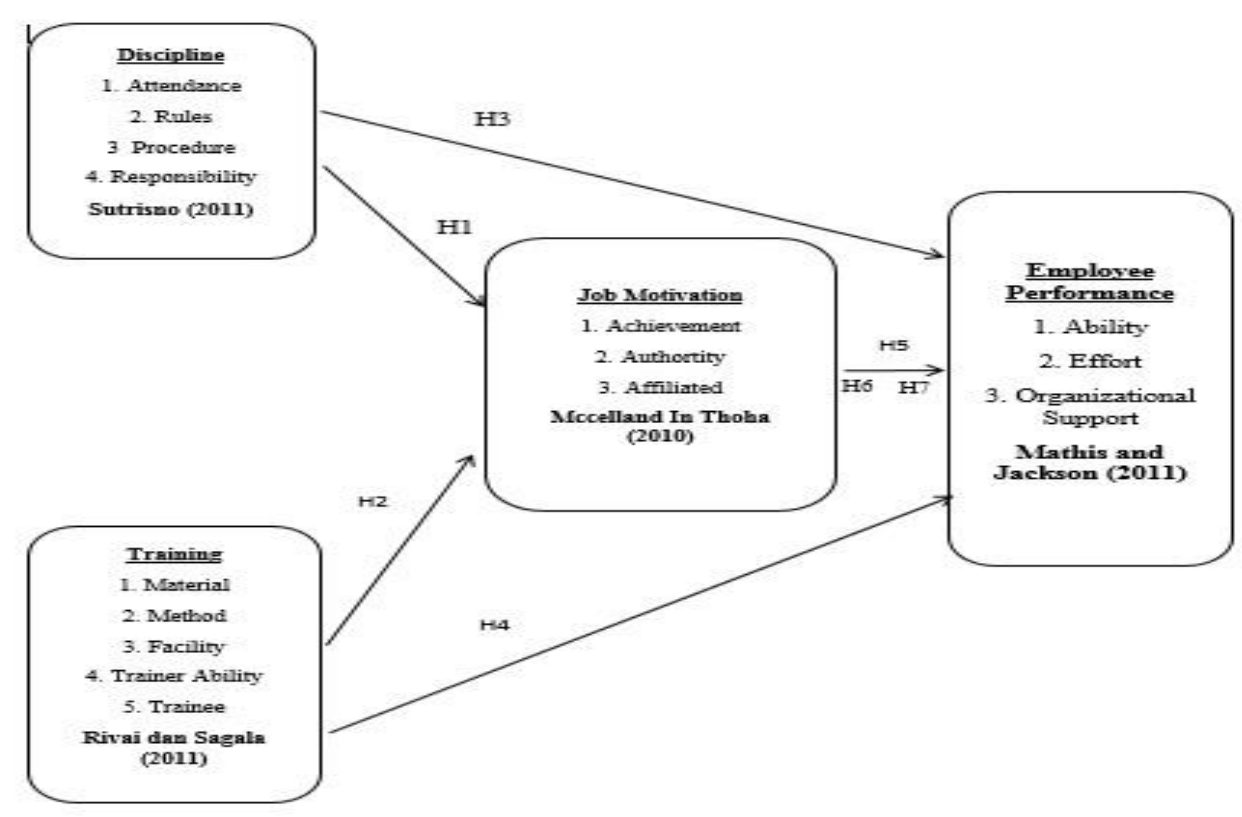

Figure 1. Conceptual Framework 


\section{RESEARCH METHODS}

\section{Research variable}

In the study, the independent variables used were Discipline (X1) and Training (X2), while the dependent variables in this study were Job motivation (Y1) and Employee Performance (Y2). According to Sugiyono (2013: 59) the dependent variable is the variable that is affected or that is the result, because of the independent variable.

\section{Population and Sample}

The population used in this study is the number of all employees of PT. Vania Interior Furnishing at Jakarta's head office, 52 people. This study uses the Slovin formula, because the amount must be representative in sampling so that researchers can generalize the results of the study. In addition, the calculation also does not require a table of the number of samples, but can be done with formulas and simple calculations, where the determination of the number of samples in this study refers to the formula developed by Krejcie and Morgan (Sugiyono, 2010: 69)

\section{Method of collecting data}

In this study the data collection methods used are explained as follows:

\section{Interview}

This study uses interviews as a data collection technique. Data collection is carried out during the pre-research process of employees directly. The researchers aimed to conduct the interview because they wanted to get in-depth answers through the respondents interviewed.

\section{Questionnaire}

In the questionnaire, respondents were asked to answer in accordance with statements that researchers had made before, based on the facts that occurred. The dissemination of this questionnaire aims to find complete information about a problem that originated from respondents through statements made by researchers.

\section{Documentation}

Researchers collected sources related to understanding of the independent and dependent variables in the form of books, documents and data of PT Vania Interior Furnishing employees.

\section{FINDINGS AND DISCUSSION RESULT}

Evaluation of the Reflective Measurement Model (Outer Model) or Test Indicator The PLS method requires that the Outer Model meet the principles of validity and reliability based on the loading factor value of each construct. Outer models can be considered good if they are able to define the relationship between latent variables and their indicators. The outer model is said to meet the requirement of convergent validity when the resulting loading factor value is greater than 0.7 . where as for outer loading values below 0.5 are invalid.

\section{Evaluating the Convergent Validity Value}

The following is the calculation result of SEM PLS measurement model version 3.0, which is then seen from the value of loading factors on the indicators in each research variable. 


\section{a. Discipline}

Based on the results obtained from data processing using smartPLS version 3.0 in Picture 4.1 below, it can be seen that the indicators of each Discipline variable have a factor loading value> 0.7 . This shows that the four indicators of the discipline variable are valid and are still used in the model.

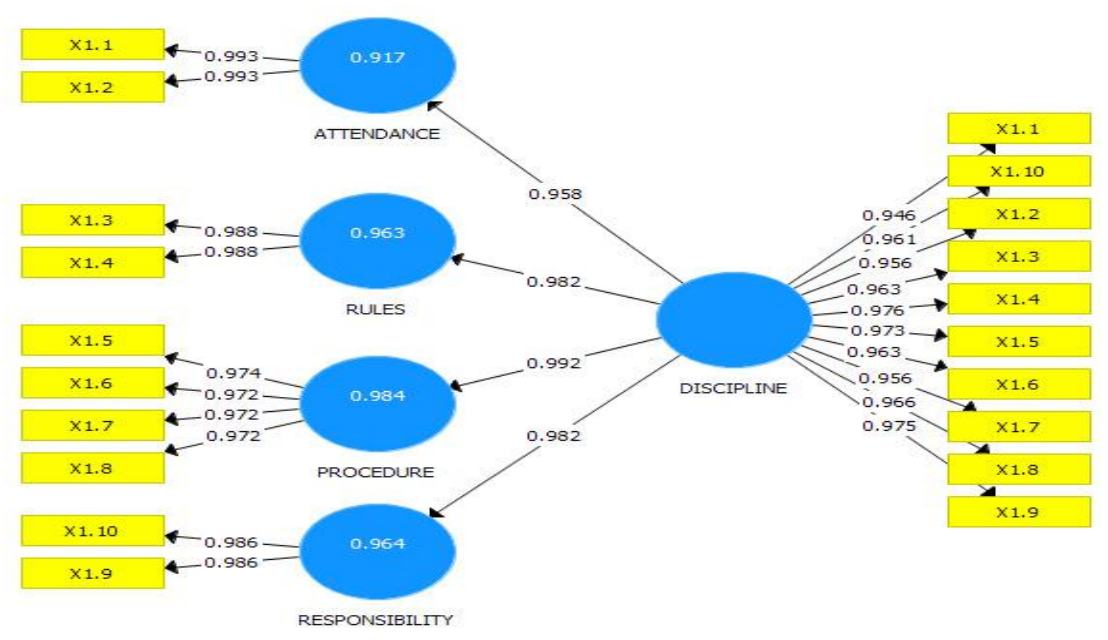

Figure 2. The result of calculations of the outer model of the Disciplinary variable

\section{b. Training}

Based on the results of data processing with smartPLS version 3.0 in Picture 4.2 below, it appears that the indicators of each Training variable have a loading factor value $>0.7$. This shows that the five indicators of Training variables are valid and are still used in the model or are not excluded from the model.

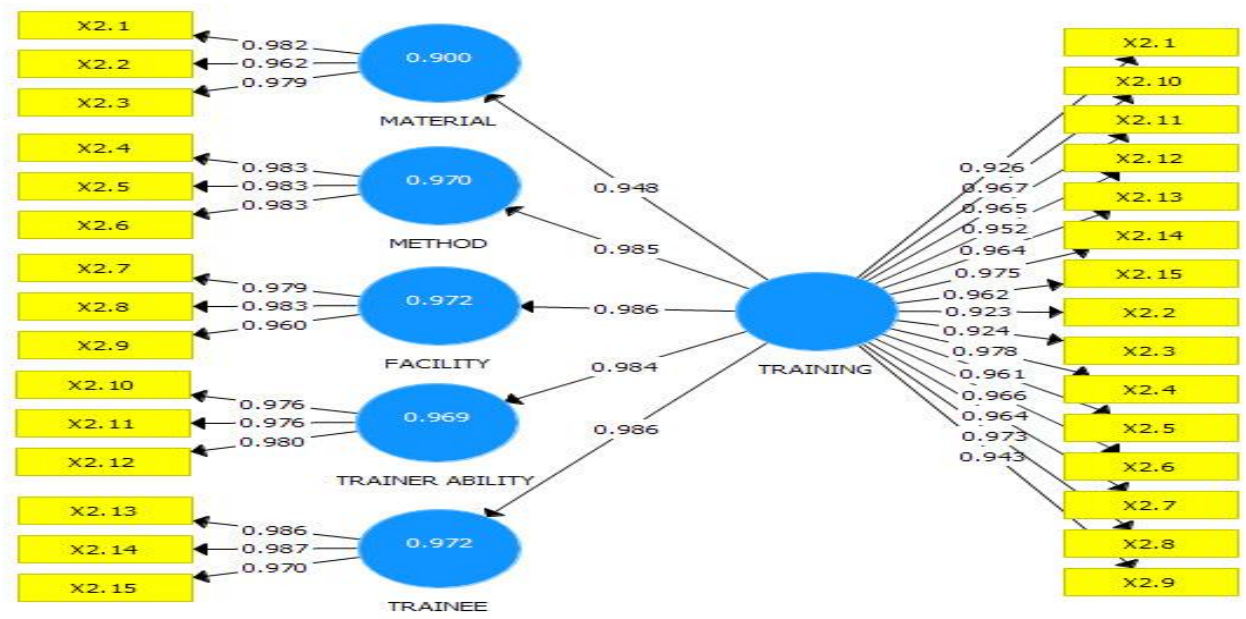

Figure 3. results of calculation of the measurement model (outer model) of Training variables 


\section{c. Job Motivation}

Based on the results of data processing with smartPLS version 3.0 in Picture 4.3 below, it appears that the indicators of each Job Motivaton variable have a loading factor value> 0.7. This shows that the three indicators of the Job Motivation variable are valid and are still used in the model or are not excluded from the model.

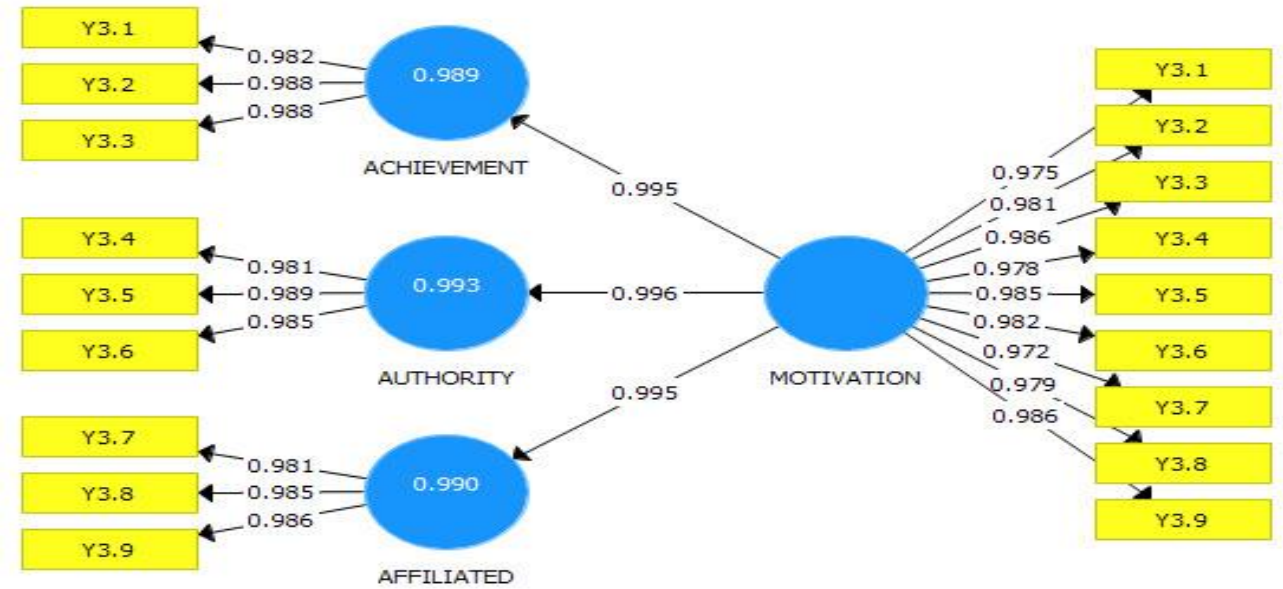

Figure 4. Results of calculation of measurement models (outer models) of Job Motivation variable.

\section{d. Employee Perfomance}

Based on the results of data processing with smartPLS version 3.0 in Picture 4.4 below, it is seen that the indicators of the Employee performance variable each have a loading factor> 0.5 . This shows that the three Employee performance indicator variables are valid and are still used in the model or are not excluded from the model.

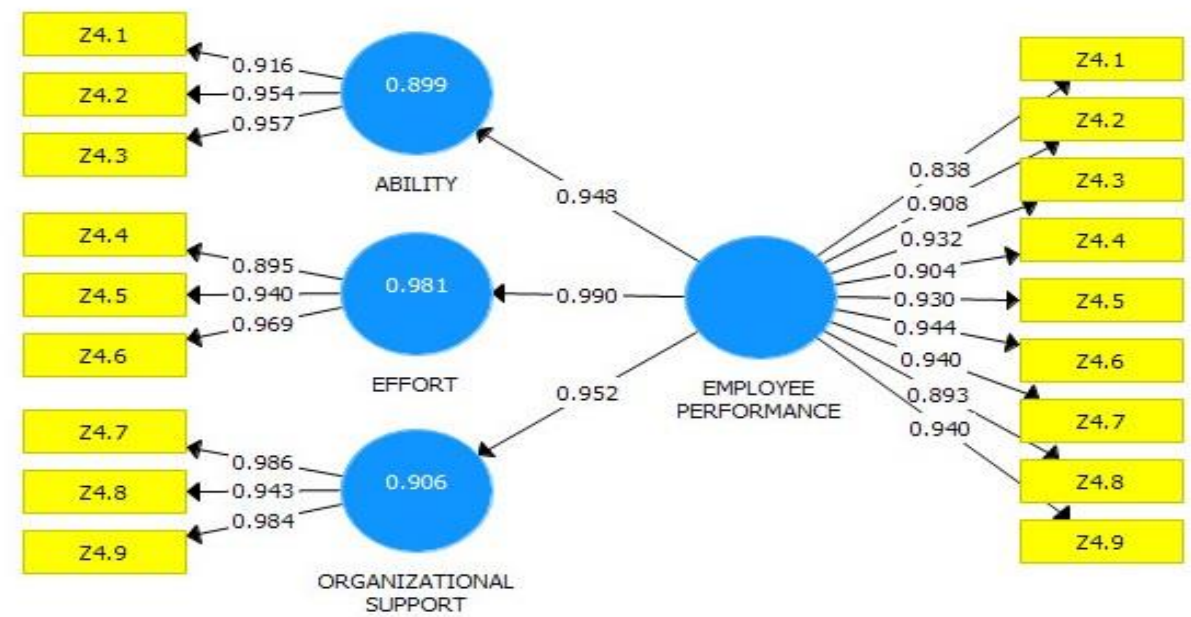

Figure 5 calculation results of the measurement model (outer model) of Employee

\section{Evaluating the Inner Model}

\section{Performance variable}

Evaluation of inner models in research aims to determine the accepted research hypothesis.Evaluation of the inner model is done by first testing the suitability of the model by looking at the coefficient of determination / R-square and second testing the significance of the relationship between variables in the model by looking at the $t$-value for the coefficient of total 
effect, indirect effect, and direct effect then determining the research hypothesis be accepted. The results of the path coefficient that illustrates the strength of the relationship between constructs / variables as shown in Figure 6 below:

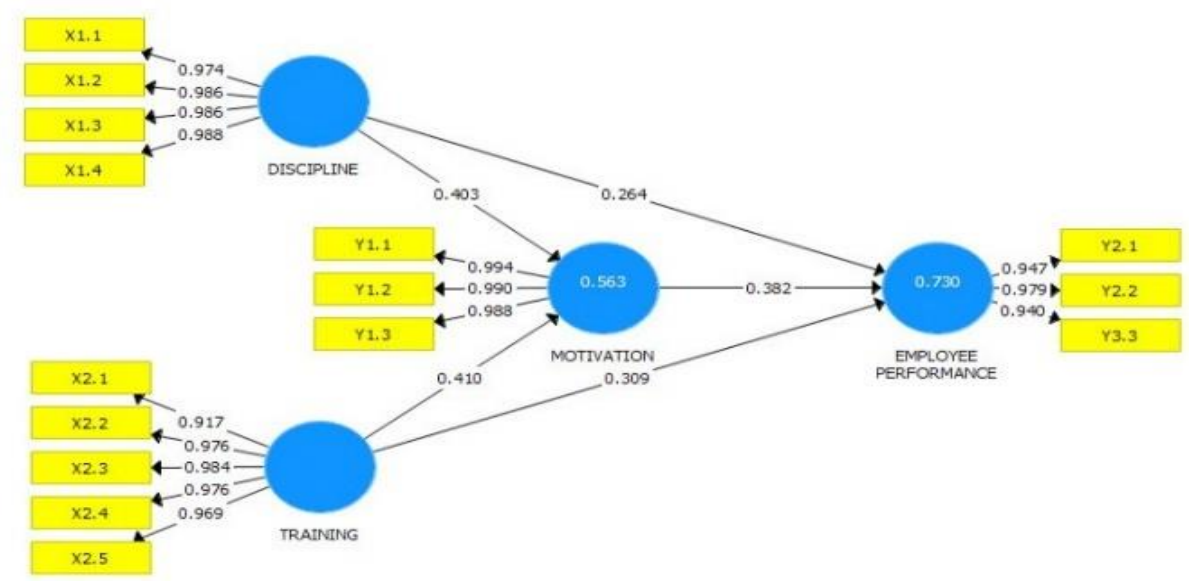

Figure 6. Path Coefficient Value

\section{Result of Hypothesis testing}

The author tests the hypothesis by comparing the t-value of the data processing results with the t-table value which is a critical value for the rejection of the null hypothesis (H0).

$\mathrm{DF}=$ degree of freed om or degree off freedom

$\mathrm{n}=$ number of observations, and $\mathrm{k}=$ number of variables.

T-table values for degrees of freedom 47 and a significance level of 0.05 amounted to 1.6779 . Taking the hypothesis is done as follows:

1) If $t$-value > of t-table or p-value <of 0.05 then hypothesis 0 is rejected.

2) If $t$-value <of t-table or $p$-value> of 0.05 then hypothesis 0 is not rejected.

T-values and p-values based on data processing using smartPLS 3.0 software are presented in table 1. below:

Table 1. Path Coefficient, t-statistic, and p-values

\begin{tabular}{|c|c|c|c|c|c|}
\hline \multicolumn{3}{|c|}{ Correlation of Construct } & $\begin{array}{l}\begin{array}{l}\text { Original } \\
\text { Sample }\end{array} \\
\text { S }\end{array}$ & t-statistic & $p$-values \\
\hline \multicolumn{6}{|l|}{$\begin{array}{l}\text { Direct } \\
\text { Effect }\end{array}$} \\
\hline Discipline & $\rightarrow$ Performance & & 0.264 & 1.989 & 0.024 \\
\hline Discipline & ->Motivation & & 0.403 & 2.961 & 0.002 \\
\hline Training & ->Performance & & 0.309 & 2.372 & 0.009 \\
\hline Training & $>$ Motivation & & 0.410 & 3.256 & 0.001 \\
\hline Motivation & $\rightarrow$ Performance & & 0.382 & 2.142 & 0.016 \\
\hline \multicolumn{6}{|c|}{ Indirect Effect } \\
\hline Discipline & ->Motivation & $\rightarrow$ Performance & 0.154 & 2.012 & 0.022 \\
\hline Training & ->Motivation & $\rightarrow$ Performance & 0.156 & 1.862 & 0.032 \\
\hline \multicolumn{6}{|l|}{ Total } \\
\hline Discipline & $\rightarrow$ Performance & & 0.418 & 3.405 & 0.002 \\
\hline Training & $\rightarrow$ Performance & & 0.466 & 3.765 & 0.000 \\
\hline
\end{tabular}

Source: Primary Data 


\section{a. Discipline Variable}

1) Direct influence on Performance (Y2)

The coefficient value shows the direct effect that if other variables are constant then Performance (Y2) is influenced by $26.4 \%$ by Discipline (X1). Thus, it can be seen that the Discipline variable significantly influences performance.

\section{2) Direct influence on Motivation (Y1)}

The coefficient value shows the direct effect that if other variables are constant then Motivation (Y1) is influenced by $40.3 \%$ by Discipline (X2). It can be concluded that Discipline (X2) has a positive and significant effect on Motivation (X3).

3) Indirect effect on Performance (Y2)

The coefficient value shows the indirect effect that if the variables Training (X2) and Motivation (Y1) are constant then Performance (Y2) is influenced by $15.4 \%$ by Discipline (X1). Thus, discipline significantly influences performance through motivation.

4) Total effect on Performance (Y2)

The total influence of the Discipline variable (X1) is 0.418 which means that the influence of the Discipline variable (X1) strengthens the influence of Motivation (Y1) on Performance (Y2).

\section{b. Training Variable}

1) Direct Effect on Performance (Y2)

The coefficient value shows the partial effect that is if other variables are constant then Performance (Y2) is influenced by $30.9 \%$ by Training (X1). Thus, it can be seen that training has a positive and significant effect on performance.

\section{2) Direct Effect on Motivation (Y1)}

The coefficient value shows the partial effect that if other variables are constant then Performance (Y2) is influenced by $41.0 \%$ by Training (X2). Thus, it can be seen that training has a positive and significant effect on motivation.

3) Indirect effect on Performance (Y2)

The coefficient value shows the indirect effect that if the variable Training (X2) and Motivation (Y1) are constant then Performance (Y2) is influenced by $15.4 \%$ by Training (X2). Thus, it can be seen that training has a significant effect on performance through motivation.

4) Total Effect on Performance (Y2)

The direct effect of the Training variable (X2) on Performance (Y2) is 0.309 and the indirect effect is 0.156 . The total effect of the Training variable (X2) is 0.466 which means that the effect of the Training variable (X2) strengthens the effect of Motivation (Y1) on Performance (Y2).

c. Motivation Variable

1) Direct influence on Performance 
The coefficient value shows the partial effect that is if other variables are constant then Performance (Y2) is influenced by $38.2 \%$ by Motivation (Y1). It can be concluded that motivation has a positive and significant effect on performance.

\section{DISCUSSION}

\section{Discipline Has Influence On Performance}

Discipline has a significant effect on performance, which matche with the hypothesis. So, high discipline will be directly proportional to the quality of performance given to employees at PT. Vania Interior Furnishing.

\section{Discipline Has Influence On Job Motivation}

Discipline has a significant and positive effect on PT. Vania Interior Furnishing because of high discipline coupled with high motivation will also achieve the company's goals.

\section{Job Motivation Has Influence on Performance}

High motivation will produce an impact on the performance given by employees to the company because with the motivation of an employee will focus on his goals, namely the company's goals.

\section{Training Has Influence on Employee Performance}

Training has a significant and positive influence on the performance of PT. Vania Interior Furnishing because good and mature training will improve employee performance to achieve company goals.

\section{Training has an influence on Job Motivation}

Training has a significant and positive influence on the job motivation of PT. Vania Interior Furnishing. because good and mature training will improve employee performance to achieve company goals.

Job Motivation has an influence to mediating both on Discipline and Training to Employee Performance

Job motivation has a significant effect for mediating discipline and training on performance. the better the job motivation, the greater the influence of the two variables.

\section{CONCLUSION AND SUGGESTION CONCLUSION}

1. Discipline has a positive effect and significant on employee performance at PT. Vania Interior Furnishing.

2. Discipline has a positive and significant effect on employee Job motivation at PT. Vania Interior Furnishing. 
3. Job motivation has a positive and significant effect on employee performance at PT. Vania Interior Furnishing.

4. Training has a positive and significant effect on employee performance at PT. Vania Interior Furnishing.

5. Training has a positive and significant effect on employee Job motivation at PT. Vania Interior Furnishing.

6. Job motivation has a positive and significant effect on mediating the effect of Discipline on Employee Performance at PT. Vania Interior Furnishing.

7. Job motivation has a positive and significant effect on mediating the effect of training on employee performance at PT. Vania Interior Furnishing

\section{SUGGESTION}

1. Management has need to design and implement a Rewards \& Punishment system by objectively and systematically in order to increase employee discipline.

2. Management has need to provide appreciation, career paths and opportunities to get better income for employee who have a good level of discipline in order to increase job motivation for employee.

3. Management has need to create a participatory and conducive work culture in order to improve Job motivation for employee performance.

4. Management has need to improve the quality of training material again in order to improve employee performance.

5. Management has need to improve training materials that are more interesting and easily to understood again in order to increase employee motivation.

6. Management has need to improve employee Job motivation by providing a good Role model of leadership so that employee discipline is more better for improving employee performance.

7. Management has need to improve employee Job motivation by providing Team work training. In order to foster a high spirit of affiliation to achieve better employee performance.

\section{REFERENCE}

Danang, Sunyoto. (2012). Human Resource Management. Jakarta: PT Buku Exclamation.

Dessler, Gary. (2011). Human Resource Management. Index Publisher, Jakarta

Dessler, Gary. (2013). Human Resource Management. 13th edition. London: Pearson.

Edy Sutrisno. (2013). Human Resource Management. Kencana, Jakarta.

Hasibuan, Malayu. (2013). Human Resource Management. Jakarta: Earth Literacy.

Hasibuan, Malayu. (2013). Human Resource Management. Jakarta: Earth Literacy. Third. Forward Mandar. Bandung.

Kotler, Philip and Armstrong, Gary, (2014), Principles of Marketing, 12th Edition, Volume Translation Bob Sabran Jakarta: Erlangga.

Mangkunegara, Anwar Prabu. (2016). Human Resource Management. Company. Bandung:PT Remaja Rosdakarya.

Mathis Robert L. dan Jackson John H. 2011. Human Resource Management. Salemba Empat. Jakarta.

Priansa, Donni. (2014). HR Planning and Development. Bandung Alphabet Publisher. 
Sugiyono, 2013, Quantitative, Qualitative, and R\&D Research Methodology. (Bandung: ALFABETA)

Rivai, Veithzal. 2011, Human Resource Management for Companies: from Theory to Practice, Jakarta: RajaGrafindo Persada

Thoha, Miftah. (2010). Organizational Behavior Basic Concepts and Its Applications. PT Raja Grafind o Persada. Jakarta.

Veithzal Rivai and Ella Jauvani Sagala, 2011. Human Resource Management for Study from Theory to Practice. PT Raja Grafindo, Jakarta 